\title{
Mengembangkan Desa Wisata Kreatif Perdamaian Sebagai Upaya Menghadirkan Shalom di tengah Ancaman Disintegrasi Bangsa
}

Agus Supratiknoํ, Suharyadi2, Rini Katika Hudiono ${ }^{3}$, Evi Maria ${ }^{4}$ 1, 2,3,4 Universitas Kristen Satya Wacana, Salatiga, Jawa Tengah

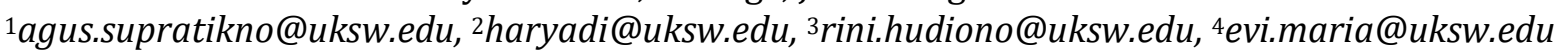

\begin{tabular}{|c|c|}
\hline $\begin{array}{l}\text { Article History } \\
\text { Submitted: } \\
\text { 12 September } 2020 \\
\text { Revised: } \\
\text { 22 October } 2020 \\
\text { Accepted: } \\
23 \text { October } 2020\end{array}$ & $\begin{array}{l}\text { Abstract: This paper is an analytical study of "Peace Creative Tourism Village" } \\
\text { initiated by the Creative and Peace Srumbung Gunung Society (CPSS). The } \\
\text { analysis is carried out using sustainable tourism theory and socio-theological } \\
\text { perspective through exploring the meaning of shalom. Srumbung Gunung } \\
\text { Hamlet has the potential, both physically and non-physically, to be developed } \\
\text { into a Peace Tourism Village. The physical potential of Srumbung gunung } \\
\text { hamlet includes beautiful mountain views, traditional arts, and historical sites. } \\
\text { Meanwhile, the non-physical potential is having local traditions and culture, }\end{array}$ \\
\hline $\begin{array}{l}\text { Keywords: } \\
\text { shalom, tourism } \\
\text { village, } \\
\text { sustainable } \\
\text { tourism, socio- } \\
\text { theological } \\
\text { perspective }\end{array}$ & $\begin{array}{l}\text { having local wisdom, still living the values of harmony and mutual cooperation } \\
\text { in the plural Srumbung Gunung community. All of these potentials are } \\
\text { synergized into capital to build a peace tourism village with an emphasis on the } \\
\text { dimension of peace as its branding. The research results show that DWK "P" } \\
\text { can be a model for a tourist village to bring peace (shalom) in the midst of the } \\
\text { threat of national disintegration. }\end{array}$ \\
\hline $\begin{array}{l}\text { shalom, desa } \\
\text { wisata, wisata } \\
\text { berkelanjutan, } \\
\text { perspektif sosio- } \\
\text { teologis }\end{array}$ & $\begin{array}{l}\text { Abstrak: Tulisan ini adalah kajian analisis "Desa Wisata Kreatif Perdamaian" } \\
\text { yang diinisiasi oleh Creative and Peace Srumbung Gunung Society (CPSS). } \\
\text { Analisis dilakukan dengan menggunakan teori sustainable tourism dan } \\
\text { perspektif sosio-teologis melalui menggali makna shalom. Dusun Srumbung } \\
\text { Gunung mempunyai potensi, baik secara fisik maupun non-fisik untuk } \\
\text { dikembangkan menjadi Desa Wisata Perdamaian. Potensi fisik yang dimiliki } \\
\text { dusun Srumbung Gunung, antara lain pemandangan pegunungan yang indah, } \\
\text { kesenian-tradisional, dan situs-situs bersejarah. Sedangkan potensi non-fisiknya } \\
\text { adalah memiliki tradisi dan budaya lokal, memiliki kearifan lokal, masih } \\
\text { hidupnya nilai-nilai kerukunan dan kegotongroyongan dalam masyarakat } \\
\text { Srumbung Gunung yang plural. Semua potensi tersebut disinergikan menjadi } \\
\text { modal untuk membangun desa wisata perdamaian dengan penekanan pada } \\
\text { dimensi perdamaian sebagai branding. Hasil analisis menunjukkan, DWKP } \\
\text { dapat menjadi salah satu model desa wisata sebagai sebuah upaya untuk } \\
\text { menghadirkan damai (shalom) di tengah-tengah ancaman disintegrasi bangsa. }\end{array}$ \\
\hline
\end{tabular}

\section{Pendahuluan}

Ancaman disintegrasi bangsa bukanlah sesuatu yang mengada-ada. Pernyataan tersebut dilandaskan kepada berbagai persoalan yang dihadapi oleh bangsa ini dalam dua dekade terakhir. Ada empat persoalan yang diidentifikasi dapat mengancam disintegrasi bangsa. Pertama, terjadinya konflik yang bernuansa agama di beberapa daerah: Konflik Poso, Ambon, Tolikara, Aceh, Lampung Selatan, Situbondo, Sampang. ${ }^{1}$ Ada banyak yang menjadi korban dari konflik tersebut, dari ratusan orang yang terluka hingga ratusan bahkan ribuan nyawa

${ }^{1}$ https://hukamnas.com/contoh-konflik-antar-agama 
melayang. Konflik juga telah mengakibatkan luka traumatis yang sewaktu-waktu bisa kembali memicu konflik baru. Kedua, persoalan intolerasi yang terjadi dalam kehidupan umat beragama. Intoleransi bisa terjadi tidak hanya di antara umat dalam satu agama, tetapi juga bisa terjadi antaragama. Intoleransi yang terjadi dalam satu agama bahkan ditemukan bisa lebih keras dibandingkan intoleransi antar-agama. ${ }^{2}$ Intoleransi juga bisa terjadi di antara aliran, denominasi dan mazhab berbeda di dalam satu agama tertentu. Oleh sebab itu, Azra menyebut intoleransi dalam kehidupan beragama bisa terjadi berlapis-lapis. Salah satu contoh konflik seagama adalah konflik di antara pengikut Ahlus Sunnah Wal Jamaah dengan penganut Islam Syiah yang terjadi di Sampang.

Konflik antaragama yang lain juga terjadi di Dusun Nangkernang, Desa Karang Gayam, Kecamatan Omben, Kabupaten Sampang, Madura Jawa Timur. Penyerangan terjadi pada 2012 silam yang menyebabkan dua orang warga Syi'ah tewas dan enam mengalami luka berat dan puluhan lainnya mengalami luka berat seperti penyebab Israel dan Palestina berperang. Konflik ini sebenarnya sudah berlangsung lama, sejak tahun 2004. Klimaksnya adalah aksi pembakaran rumah ketua Ikatan Jamaah Ahl Al-Bait (IJABI) dan 2 rumah jamaah syi'ah serta sebuah mushola yang digunakan sebagai sarana ibadah. Aksi tersebut dilakukan oleh sekitar 500 orang yang mengklaim diri sebagai pengikut Ahlus Sunnah Wal-Jamaah. ${ }^{3}$

Ketiga, disintergasi bangsa terjadi karena paham radikalisme berkembang pesat dan telah memicu lahirnya aksi kekerasan dan terorisme. Paham radikalisme bahkan melahirkan gagasan untuk mengganti dasar negara Pancasila dengan ideologi khilafah. Di Indonesia, benih ide khilafah sudah ada sejak awal kemerdekaan tahun 1945, baik yang bersifat konstitusional, seperti Majelis Konstituante; atau bersifat militer, seperti dalam kasus DI/TII, yang berusaha mendirikan negara Islam dan menolak Pancasila. Di era reformasi tahun 1998 yang memberikan ruang kebebasan publik, isu khilafah semakin intens dan terbuka dikampanyekan, baik lewat opini-opini pemikiran maupun gerakan nyata. Seperti mewacanakan Islam sebagai solusi dan ideologi alternatif mengusahakan bentuk pemerintahan Negara Indonesia dari Negara kesatuan berformat republik menjadi khilafah, berikut konstituisi Negara sejak dari Undang-Undang Dasar 1945 dan hukum positif diangkat dari syari'ah Islamiyah seutuhnya. ${ }^{4}$ Hizbut Tahrir Indonesia sebagai salah satu gerakan yang mendukung berdirinya Negara Islam adalah yang termasuk salah satu gerakan radikal yang berideologi khilafah.

Keempat, disintegrasi bangsa terjadi karena menguatnya politik identitas berbasis suku, ras dan agama, serta politisasi agama. Politisasi agama di Indonesia telah mampu membelah masyarakat dalam dua ideologi, yaitu nasionalis dan agama. Sentimen keagamaan yang muncul dalam Pemilihan Kepala Daerah (Pilkada) DKI Jakarta tahun 2017 adalah bukti bahwa politisasi agama yang dilakukan oleh tim kandidat calon kepala daerah berhasil membelah masyarakat Indonesia menjadi dua ideologi, yaitu nasionalis dan agama. ${ }^{5}$

Besarnya ancaman disintegrasi bangsa dan sifatnya yang multidimesial memanggil setiap warga bangsa ini untuk secara bergotong royong ikut menghadapi dan mencari solusinya.

${ }^{2}$ Azumardi Azra, Intoleransi Keagamaan. PPIM, UIN Jakarta.

https://ppim.uinjkt.ac.id/penelitian/intoleransi-keagamaan/ di akses 9 September 2020.

${ }^{3}$ https://hukamnas.com/contoh-konflik-antar-agama

${ }^{4}$ https://islam.nu.or.id/post/read/55557/khilafah-dalam-pandangan-nu

${ }^{5}$ Sugit Arjon, Religious Sentiments In Local Politics. Jurnal Politik, 3 No.2 (2018): 171-198. 
Sifat mutidimensial ancaman tersebut menuntut pendekatan mutidimensial untuk mengatasinya. Menggunakan hanya salah satu pendekatan, semisal keamanan yang bersifat militerisme tidak akan mampu mengatasinya secara tuntas bahkan bisa menimbulkan persoalan baru menawarkan pendekatan untuk menggerakkan perdamaian, yaitu menggunakan pariwisata. Argumennya, wisata dapat memberikan kedamaian bagi pelakunya. Konsep perdamaian mencakup enam dimensi, yaitu berdamai dalam diri sendiri, berdamai dengan orang lain, berdamai dengan alam rumah bersama, berdamai dengan generasi lama dengan menghormati budaya, warisan, dan prestasi generasi sebelumnya; berdamai dengan generasi mendatang yang diwujudkan melalui gaya hidup dan praktik yang berkelanjutan, dan berdamai dengan Pencipta, dengan mempraktikkan asas universal dari semua agama dan humanisme. ${ }^{6}$ Oleh sebab itu, setiap wisatawan memiliki potensi untuk menjadi "Duta Perdamaian".

Sebuah studi di Nepal memberikan bukti bahwa pariwisata dapat digunakan untuk mempromosikan pilar perdamaian, yaitu kemakmuran, kesetaraan, dan filantropi. ${ }^{7}$ Oleh sebab itu, pariwisata efektif untuk meminimalkan prasangka dan mispersepsi. Pariwisata bahkan dapat menjadi kekuatan untuk memperbaiki dan memulihkan hubungan antara sesama manusia, sehingga dunia dapat menjadi lebih damai. Pariwisata tidak hanya berkontribusi secara ekonomi, tetapi juga memungkinkan terjadi pertukaran budaya, saling pengertian dan kerjasama di antara masyarakat. Terlepas dari kekurangan tertentu, pariwisata secara signifikan berkontribusi pada dunia yang lebih damai. ${ }^{8}$ Butler menyatakan, perjalanan antara negara-negara yang terpecah secara politik dapat membantu mengurangi ketegangan dan mempromosikan pemahaman politik yang lebih besar. ${ }^{9}$ Selanjutnya Schneider menjelaskan hasil identifikasinya, kegiatan wisata diidentifikasi dapat menumbuhkan empati warga Palestina atas orang Israel, meskipun faktanya kedua negara tersebut terlibat konflik. ${ }^{10}$ Pariwisata mempromosikan transformasi konflik yang berakar pada toleransi, dialog, dan kerja sama. Pariwisata terbukti dapat digunakan sebagai media untuk mengurangi prasangka, mengubah pandangan politik dan menginspirasi komitmen untuk perdamaian dan aktivis keadilan. ${ }^{11}$

Selama tiga atau empat dekade terakhir, Farahani \& Dogra menemukan, berbagai pemangku kepentingan telah menyadari bahwa pariwisata dapat memainkan peran penting dalam mewujudkan dan memelihara perdamaian. Pariwisata menciptakan pemahaman dan kepecayaan di antara manusia yang memiliki latar belakang yang berbeda. Namun, menemukan bahwa pariwisata berbanding lurus dengan perdamaian, artinya jika suatu destinasi ada yang damai, maka pariwisata dapat meningkatkan nilai perdamaian para pengunjungnya, begitu pula sebaliknya. Destinasi wisata menjadi faktor penting penyebaran nilai perdamaian

${ }^{6}$ Louis d'amore (2014). Peace through Tourism: An Historical and Future Perspective. In P. E. of the K. the Centre of Peace Research University/Austria (Ed.), International Handbook on Tourism and Peace (pp. 355368). Drava.

${ }^{7}$ Mukunda Neupane, Tourism as a Catalyst for Peace: Analyzing the Bright Sides of Tourism in Nepal. (Issue May). Thesis Centria University of Applied Science, Nepal (2013): 45

${ }^{8}$ Ibid., 46-48.

${ }^{9}$ R. W. Butler \& B. Mao \& B Mao,. (1995). Tourism between divided quasi- states: International, domestic or what? In R. W. Butler \& D. Pearce (Eds.), Change in Tourism: People, Places, Processes. Routledge. (1995):92-113

${ }^{10}$ Maureen Schneider, (2019). Touring for peace: the role of dual-narrative tours in creating transnational activists. International Journal of Tourism Cities, 5(2), 209.

${ }^{11}$ Ibid., 216. 
bagi pengujungnya. Oleh sebab itu, menjadi penting untuk menciptakan destinasi wisata yang lebih ramah dan menyediakan material yang diperlukan untuk kontak antara orang-orang yang pada akhirnya menggerakkan orang-orang tersebut ke arah resolusi konflik dan perdamaian secara keseluruhan. ${ }^{12}$

Kelompok riset lainnya, Salazar mengingatkan meskipun penting untuk mengakui kekuatan positif yang dapat dimiliki pariwisata sebagai industri terbesar di dunia, pariwisata memiliki dampak sosio-budaya, ekonomi, lingkungan, dan politiknya. Karena itu, perlu mencermati perbedaan antara kekuatan retorika pariwisata misalnya ekowisata, pariwisata berkelanjutan, dan perdamaian melalui pariwisata dengan kenyataan di lapangan Salazar lebih lanjut menyatakan bahwa mewujudkan perdamaian melalui pariwisata perlu dialog yang lebih terbuka di antara seluruh pemangku kepentingan. ${ }^{13}$ Menurut Litvin dalam, Tourism: the world Peace's Industry? Pariwisata bersama dengan banyak industri lainnya, merupakan penerima manfaat keuntungan dari perdamaian bukan penggerak perdamaian. Meskipun demikian ia mengakui bahwa pariwisata berkontribusi dalam menambah toleransi budaya dan kesalingpahaman. ${ }^{14}$ Litvin dan Salazar mengakui bahwa pariwisata berkontribusi dalam menambah toleransi budaya dan kesalingpahaman. Ada banyak contoh 'praktik yang baik' dari bentuk alternatif pariwisata yang berkontribusi pada resolusi konflik, pemahaman antar budaya yang lebih baik, dan bahkan keadilan sosial global. Namun pertanyaannya, bagaimana pariwisata secara keseluruhan berkontribusi pada perdamaian dunia lebih kompleks. Tentu bukan suatu praktik yang mudah. Oleh sebab itu, isu tentang pariwisata dan perdamaian masih menarik untuk diteliti dan dikaji dalam riset.

Dalam konteks riset Indonesia, Ariana telah meneliti wisata damai di Monumen Ground Zero di Bali. Wisata damai tersebut bertujuan untuk memperingati tragedi kemanusian dan memulihkan keharmonisan hidup masyarakat atas tragedi Bom Bali. ${ }^{15}$ Untuk membangun wisata damai perlu memperhatikan potensi-potensi daerah. Pertama, potensi fisik, yaitu sebagai komponen wisata damai yang bisa dilihat di lapangan, seperti tempat ibadah, keindahan pantai dan pemukiman masyarakat. Kedua, potensi nonfisik yang abstrak sebagai bagian potensi untuk dikembangkannya peace tourism, seperti sejarah, hubungan antar umat beragama, kearifan lokal, adat istiadat masyarakat, multikultur/pluralisme, dan kesadaran masyarakat. ${ }^{16}$ Namun, riset tentang pariwisata dan perdamaian masih sedikit. ${ }^{17}$ Oleh sebab itu, riset ini mencoba untuk meneliti pariwisata dan perdamaian di Dusun Srumbung Gunung, Desa Poncoruso, Kabupaten Semarang.

${ }^{12}$ Benafsheh M. Farahani and Jeed Dogra (2014). An Inter-Relational Study of Achieving Peace Through Tourism. In P. S. Manhas, D. R. Gupta, \& A. Gupta (Eds.), Strategic Development Policies and Impact Studies of Sustainable, Rural and Community - based Tourism (Issue July, pp. 127-137). Primus Book.

${ }^{13}$ Noel B. Salazar, Building a 'Culture of Peace' through Tourism: Reflexive and analytical notes and queries

${ }^{14}$ Stephen W. Litvin, Tourism: The World's Peace Industry? Journal of Travel Research, Volume 37 No. 1 August 1998, $63-66$

${ }^{15}$ Nyoman Ariana, Penelusuran Wisata Damai Monumen Ground Zero Kuta. (Bali: Pustaka Larasan, 2017), 9 .

${ }^{16}$ Ibid., 30-31.

${ }^{17}$ Ibid., 21. 
Tujuan penelitian ini adalah untuk merintis Desa Wisata Kreatif Perdamaian (DWKP) Srumbung Gunung yang dapat menghadirkan kedamaian (shalom) dalam pariwisata. Riset ini akan mengidentifikasi nilai-nilai perdamaian seperti apakah yang dapat dihadirkan di DWKP Srumbung Gunung. Sejalan dengan riset Farahani \& Dogra bahwa pariwisata dapat memainkan peran yang penting dalam mewujudkan dan memelihara perdamaian, Dusun Srumbung Gunung, Desa Poncoruso, Kabupaten Semarang diharapkan dapat menjadi salah satu destinasi wisata yang dapat menyebarkan nilai perdamaian kepada para pengunjungnya, sehingga mendorong orang banyak untuk hidup rukun dan damai ditengah perbedaan agar ancaman disintegrasi bangsa dapat diminimalisir. Desa dipilih sebagai tempat riset karena desa-desa di Indonesia diidentifikasi memiliki nilai kearifan lokal, seperti gotong royong dan persaudaraan yang kuat di tengah keragaman sebagai penawar ancaman disintegrasi bangsa.

Riset ini membahas nilai-nilai perdamaian di DWKP Srumbung Gunung dari perpektif teori pengembangan pariwisata berkelanjutan (sustainable tourism) dan perpektif sosioteologis melalui pemaknaan kata shalom. Persepektif teori pengembangan pariwisata berkelanjutan dipilih digunakan dalam kajian ini karena prinsip teori ini mampu untuk mengurangi aspek negatif dalam pembangunan dan pengembangan sektor wisata, seperti potensi kerusakan alam, komunitas, budaya dan masyarakat. ${ }^{18}$ Sustainable tourism fokus pada pengelolaan semua sumber daya, sehingga kebutuhan ekonomi, sosial dan estetika dapat dipenuhi dengan tetap menjaga integritas budaya, proses ekologi esensial, keanekaragaman hayati dan sistem pendukung kehidupan. Pengembangan sektor wisata memerlukan integrasi pendekatan pencegahan ketika membuat strategi pariwisata, rencana dan tindakan pembangunan di semua tingkat tata kelola organisasi. Sustainable tourism fokus pada keberlanjutan ekonomi, keberlanjutan ekologi, keberlanjutan budaya, dan keberlanjutan lokal. ${ }^{19}$

Selain mengkaji dari aspek teori-teori sustainable tour, riset ini juga mengkaji nilai perdamaian dari perspektif sosio-teologis dengan melihat relevansi nilai wisata perdamaian dari makna kata shalom. Shalom adalah konsep kritis dalam Perjanjian Lama Ibrani yang muncul sebanyak 397 kali. Dalam terjemahan bahasa Inggris modern seperti NIV, ada 113 tempat di mana shalom diterjemahkan sebagai “perdamaian". ${ }^{20}$ Pertama, Tuhan menjanjikan bangsa Israel keadaan yang harmonis antara mereka, musuh mereka dan bahkan binatang buas di sekitar mereka "Aku akan memberi damai sejahtera di dalam negeri itu, sehingga kamu akan berbaring dengan tidak dikejutkan oleh apapun; Aku akan menyingkirkan binatang buas dari nege itu, dan pedang tidak akan melintasdi negerimu" (Im. 26:6). Kedua, shalom sebagai atribut Tuhan. Gideon mendeklarasikan shalom ini sebagai atribut Tuhan: "Jadi Gideon membangun sebuah mezbah untuk Tuhan di sana dan menyebutnya The Lord Is Peace" (Hak. 6:24, NIV). Konteksnya adalah Gideon berasumsi dia akan mati setelah melihat malaikat Tuhan. Namun, itu tidak akan menjadi masalah. Menanggapi hal tersebut, Gideon

\footnotetext{
${ }^{18}$ Adriana Budeanu, Impacts and responsibilities for sustainable tourism: A tour operator's perspective. Journal of Cleaner Production, 13, 2, (2005): 89.

${ }^{19}$ UNEP \& WTO, Making Tourism more Sustainable: A Guide for Policy Makers (United Nations Environment Programme and World Tourism Organization, 2005), 9.

${ }^{20}$ Goodrick, E.W. \& Kohlenberger, III, J.R., Zondervan NIV Exhaustive Concordance, 2nd edn., (Zondervan, Grand Rapids, MI, 1999), 1500
} 
menyatakan bahwa shalom sebagai bagian dari ko-drat Tuhan dan Tuhan memberikan kedamaiannya pada konteks apa pun dan orang yang dipilih.

Ketiga, shalom menggambarkan pemuliaan Tuhan atas umat-Nya. Contoh seperti apa yang dilakukan oleh pemazmur Daud yang menggambarkan shalom sebagai pemuliaan Tuhan atas umat-Nya, "Tuhan memberi kekuatan kepada umatnya; Tuhan memberkati umat-Nya dengan damai" (Mzm. 29:11). Berkat perdamaian datang dari Tuhan. Contoh lain adalah ketika Israel merebut kembali tanah dari musuh-musuhnya, "Kota-kota yang direbut orang Filistin dari Israel, kembali pula kepada Israel...Dan ada perdamaian antara Israel dan orang Amori" (1Sam. 7:14). Setelah mendapatkan wilayah itu, Israel dan orang Amori memasuki musim shalom hidup berdampingan secara damai.

Selanjutnya, menurut Yoder, kata shalom, מלֹ memiliki tiga nuansa makna: menunjuk pada keadaan secara material dan fisik; menunjuk pada hubungan yang baik; berkaitan dengan etika dan moralitas. Dalam semua rujukan yang bekaitan dengan makna material dan fisik, kata shalom menunjuk kepada kesejahteraan; baik atau baik-baik saja. Lebih dari itu, shalom juga dapat menunjuk pada kemakmuran, kelimpahan dan keamanan dari bahaya. Berdasarkan pada makna material shalom, ada dua hal yang perlu digaris bawahi, yakni: shalom ditandai dengan hadirnya kesejahteraan secara fisik, dan dengan absennya ancaman fisik seperti perang, penyakit dan kelaparan; shalom lebih menekankan makna yang bernuansa positif seperti keadaan yang baik, kesehatan, keamanan dari pada makna negatif seperti tidak ada perang.

Shalom sebagai keadilan (justice), menunjuk hubungan sosial yang damai. Hal ini sesuai dengan pemaknaan kata peace dalam bahasa Inggris. Shalom, seperti halnya peace, dapat menunjuk pada relasi positif yang baik di antara bangsa-bangsa atau kelompok-kelompok. Dalam relasi personal shalom dapat diartikan sebagai teman dekat atau sahabat. Shalom adalah sebuah tindakan untuk keadilan, kesehatan dan menciptakan hubungan dekat/ baik (relationship) di antara orang dan bangsa-bangsa.

Sementara itu, shalom sebagai moral atau etika menunjuk pada dua hal, yakni kejujuran, sebagai lawan kata dari penipu. Man of shalom secara paralel diartikan dengan orang yang jujur (honest), menjadi pribadi yang berintegritas dan berkarakter jujur. Sedangkan makna moral yang kedua dari shalom adalah keadaan tidak bercela (blameless). Jadi, dalam ranah moralitas, shalom merujuk kepada hadirnya integritas dan kejujuran sebagai lawan kata penipu, sekaligus merujuk kepada ketiadaan cela. Dari kedua kasus tersebut dapat dilihat lagi nuansa shalom bersifat positif dan aktif. Shalom adalah melakukan tindakan untuk mengubah penipuan, kemunafikan dan mempromosikan integritas kejujuran dan keterbukaan. ${ }^{21}$

Shalom adalah misi Allah (mission of God) yang bersifat holistik yang memiliki dimensi waktu baik kekinian maupun masa depan. Shalom dalam dimensi kekinian berarti bagaimana Isarel dan gereja memperjuangkan misi Allah menciptakan keselamatan, keadilan dan perdamaian (sebagai cara hidup/kesaksian). Jadi, bukan bersifat pasif terhadap status quo, tetapi aktif dan transformatif. Shalom secara eskatologis (dimensi masa depan) adalah rencana

${ }^{21}$ Perry B. Yoder, Shalom the Bible's Word for Salvation, Justice and Peace (Newtown: Faith and Life Press., 1987), 10-16 
damai sejahtera Allah bagi Israel, gereja, dunia dan segenap ciptaan-Nya. Perhatikan yang diungkapkan oleh nabi Yesaya:

Akan terjadi pada hari-hari yang terakhir gunung tempat rumah TUHAN akan berdiri tegak di hulu gunung-gunung dan menjulang tinggi di atas bukit-bukit; segala bangsa akan berduyun-duyun ke sana, dan banyak suku bangsa akan pergi serta berkata: "Mari, kita naik ke gunung TUHAN, ke rumah Allah Yakub, supaya Ia mengajar kita tentang jalan-jalan-Nya dan supaya kita berjalan menempuhnya; sebab dari Sion akan keluar pengajaran dan firman TUHAN dari Yerusalem. Ia akan menjadi hakim antara bangsabangsa dan akan menjadi wasit bagi banyak suku bangsa; maka mereka akan menempa pedang-pedangnya menjadi mata bajak dan tombak-tombaknya menjadi pisau pemangkas; bangsa tidak akan lagi mengangkat pedang terhadap bangsa, dan mereka tidak akan lagi belajar perang. (Yes. 2:1-4)

Serigala akan tinggal bersama domba dan macan tutul akan berbaring di samping kambing. Anak lembu dan anak singa akan makan rumput bersama-sama, dan seorang anak kecil akan menggiringnya (Yes. 11:6).

Pengharapan akan damai sejahtera yang mencakup seluruh dunia dan segenap ciptaan ini dalam konsep "Millennialisme" digenapi dalam kerajaan seribu tahun kejayaan Mesias di dunia sebelum penghakiman terakhir (Why. 20:1-6).

Kirk J. Franklin, menyatakan, Shalom adalah damai sejahtera sebagai cara hidup, berkat dari Tuhan, atribut Tuhan yang mencerminkan karakter kebenaran, cinta, keadilan, damai dan kesempurnaan, dan itu adalah keadaan dari Tuhan. ${ }^{22}$ Peristiwa Perjanjian Lama juga perlu dipandang secara mandiri, sebagai teologi biblikal yang mengeluarkan idenya sendiri dengan konteks pemahamannya yang tidak harus diasumsikan oleh tema-tema Perjanjian Baru. ${ }^{23}$ Dalam Konteks teologi biblikal PL makna shalom sebagai sebuah keadaan damai lebih dominan secara fisik/material dari pada spiritual, keadaan damai yang menyejarah dalam hidup bangsa Israel. Keadaan damai yang menyejarah itu memiliki dua dimensi: shalom yang dijanjikan Allah, yang akan dialami dalam sejarah kehidupan Israel, jika mereka menaati kehendak-Nya; dan, shalom sebagai sebuah cara hidup yang harus diperjuangkan oleh bangsa Israel sebagai bentuk kesaksian mereka untuk menjalankan misi Allah (God's mission).

\section{Metode Penelitian}

Riset ini menggunakan pendekatan kualitatif. Pendekatan ini menghasilkan data deskriptif yang berbentuk tulisan dan deskripsi perilaku dari orang yang diamati. Riset kualitatif membuka kesempatan bagi para peneliti untuk dapat lebih mengenali subjek yang diamati dan merasakan apa yang dialami subyek dalam kehidupan sehari-harinya. Riset ini diharapkan dapat menghasilkan deskripsi mendalam terkait ucapan, tulisan, dan/atau perilaku yang diamati dari suatu individu, kelompok, masyarakat, dan/atau suatu organisasi tertentu dalam pengaturan konteks tertentu yang dikaji dari sudut pandang yang utuh, komprehensif, dan holistik. ${ }^{24}$

\footnotetext{
${ }^{22}$ Kirk J. Franklin., 2020, 'Searching for shalom: Transformation in the mission of God and the Bible translation movement', HTS Teologiese Studies/ Theological Studies 76(4), a5879. https://doi.org/ 10.4102/hts.v76i4.5879

${ }^{23}$ Harls Evan Siahaan, Mengajarkan Nasionalisme Lewat Momentum Perayaan Paskah: Refleksi Kritis Keluaran 12:1-51. DUNAMIS (Jurnal Teologi dan Pendidikan Kristiani), Vol. 1, No. 2, (April 2017): 45.

${ }^{24}$ Sukidin \& Basrowi, Metode Penelitian Kualitatif Perspektif Mikro (Surabaya: Insan Cendikia, 2002), 
Creswell, mengidenti-fikasi enam asumsi paradigma riset kualitatif. Pertama, riset lebih fokus pada proses dari pada hasil. Kedua, riset lebih fokus pada makna manusia. Ketiga, instrumen utama untuk mengumpulkan analisis data berupa gambar. Keempat, peneliti masuk ke dalam lapangan penelitian, berelasi dengan orang, latar, lokasi, atau institusi untuk mengamati dan menganalisis perilaku informan. Kelima, riset bersifat deskriptif, artinya riset lebih fokus pada proses, makna, dan pemahaman yang didapat melalui kata atau bagaimana orang membuat hidup, pengalaman, dan struktur dunianya. Keenam, riset bersifat induktif, dengan membangun abstraksi, konsep, hipotesa, dan teori dari rincian data dan fakta. ${ }^{25}$

Data-data dalam riset ini dikumpulkan dengan beberapa cara. Pertama, data dikumpulkan dengan melakukan observasi partisipatif di Dusun Srumbung Gunung, Desa Poncoruso, Kabupaten Semarang. Kedua, data dikumpulkan dari wawancara mendalam dengan aktor kunci, seperti pemerintah desa, tokoh-tokoh masyarakat desa, organisasi kepemudaan yang tergabung dalam Karang Taruna dan Creative Peace Srumbung Society (CPSS), masyarakat desa. Ketiga, data dikumpulkan melalui studi pustaka tentang pariwisata dan perdamaian, serta makna sosio-teologis dari kata shalom.

\section{Pembahasan}

Desa Wisata Kreatif "Perdamaian" (DWKP) sebuah model wisata desa yang dirancang dengan mengedepankan aspek "perdamaian" sebagai branding yang membedakan dengan desa wisata lainnya. Branding merupakan upaya untuk menjadikan sesuatu yang biasa dan meningkatkannya menjadi sesuatu yang lebih berharga dan berarti. ${ }^{26}$ DWKP dirancang sebagai sebuah model desa wisata dengan branding "perdamaian" sebagai kontribusi lokal (desa) untuk menghadirkan damai (shalom) di tengah-tengah ancaman disintegrasi bangsa. Dalam tahapan awal pembangunan DWKP, langkah yang dilakukan adalah melakukan eksplorasi terhadap potensi-potensi yang ada di Dusun Srumbung Gunung, Desa Poncoruso, Kecamatan Bawen, Kabupaten Semarang. Ariana, membagi potensi wisata menjadi dua, yaitu potensi fisik dan potensi non-fisik. Batasan komponen fisik semisal tempat ibadah, keindahan pantai dan pemukiman masyarakat. Sedang-kan cakupkan eksplorasi potensi non-fisiknya meliputi: sejarah, hubungan antarumat beragama, kearifan lokal, adat istiadat masyarakat, multikultur/ pluralisme, dan kesadaran masyarakat. ${ }^{27}$

Hasil identifikasi Dusun Srumbung Gunung memiliki potensi fisik dan potensi nonfisik. Potensi fisik Dusun Srumbung Gunung, antara lain: Pertama, nilai pusaka saujana, terdiri dari pemandangan gunung Ungaran, kawasan pertanian, sungai, dan sumber air panas; Kedua, nilai pusaka benda bersejarah, seperti beberapa situs bersejarah di area persawahan yang berbentuk patung Nandi tanpa kepala, Patung lingga Yoni, batu lumping, dan struktur batu bata. Sedangkan potensi non-fisik Dusun Srumbung Gunung, yaitu: Pertama, nilai keragaman agama dan kepercayaaan. Dusun ini memiliki agama yang beragam, yakni: Islam, Kristen, Katolik, Hindu dan Penghayat Kepercayaan. Masing-masing agama memiliki tem-

\footnotetext{
${ }^{25}$ John W. Creswell, Desain Penelitian Pendekatan Kualitatif dan Kuantitatif (Jakarta: KIK Press, 2002)

${ }^{26}$ Philip Kotler and Waldemar Pfoertsch, (2006). B2B Brand Management, with the Cooperation of Ines Michi. Berlin: Springer, 3.

${ }^{27}$ Nyoman Ariana, Penelusuran Wisata Damai Monumen Ground Zero Kuta Bali (Pustaka Larasan, 2017), 30-31.
} 
pat ibadahnya. Keanekaragaman agama dan kepercayaan tidak membuat perpecahan di sana. Masyarakat dapat hidup dalam kerukunan dan kegotongroyongan. Kedua, nilai tradisi dan budaya lokal. Masyarakat di sana masih memelihara dan menghidupi tradisi, seperti Nyadran, Sedekah Desa/Merti Dusun. Ketiga, nilai kesenian tradisional. Dusun ini memiliki kelompok kesenian seperti kuda lumping, karawitan, kasidahan, dan musik gereja.

Potensi-potensi fisik mapun non fisik tersebut akan dikembangkan secara utuh dan disinergikan untuk membangun DWKP sebagai kontribusi lokal (desa) untuk ikut serta mengatasi dan mengantisipasi fenomena radikalisme dan politik identitas yang membuahkan konflik berdasarkan perbedaan agama dan budaya; meningkatkan kecintaan terhadap pertanian dan mendukung keberlanjutannya demi kesejahteraan bersama; melestarikan dan mengembangkan potensi pusaka saujana; melestarikan dan mengembangkan potensi seni, budaya, dan adat istiadat, baik yang tangible ataupun intangible untuk membentuk karakter bangsa; melestarikan benda-benda pusaka bersejarah yang terdapat di Srumbung Gunung dan mengembangkannya untuk tujuan pendidikan dan penelitian; meningkatkan kesejahteraan masyarakat melalui pengem-bangan ekonomi kreatif. ${ }^{28}$

\section{Dimensi Pariwisata Berkelanjutan (Sustainable Tourism)}

Desa Wisata Kreatif Perdamaian (DWKP) Srumbung Gunung adalah salah satu bentuk desain wisata damai. Nilai-nilai perdamaian mencakup kedamaian di dalam diri sendiri, berdamai dengan orang lain, kolaborasi antar negara, berdamai dengan alam (rumah kita/planet bumi) berdamai dengan generasi lampau yang diwujudkan dengan menghormati budaya, warisan, dan prestasi generasi sebelumnya, berdamai dengan generasi mendatang, melalui gaya dan praktik hidup yang berkelanjutan; dan damai dengan Sang Pencipta dengan mempraktekkan asas universal dari semua agama dan humanis. Semua makna damai tersebut sangat sesuai dengan makna yang ada di dalam kata shalom.

Wisata Desa Perdamaian adalah bagian dari sustainable tours. Karena itu dalam pembuatan desain DWKP didasarkan pada prinsip-prinsip pariwisata yang berkelanjutan; melibatkan semua stakeholder; berwawasan lingkungan; peka tradisi religius dan budaya lokal; hormat terhadap HAM; pemerataan keuntungan ekonomi bagi penduduk lokal (lihat gambar 1).

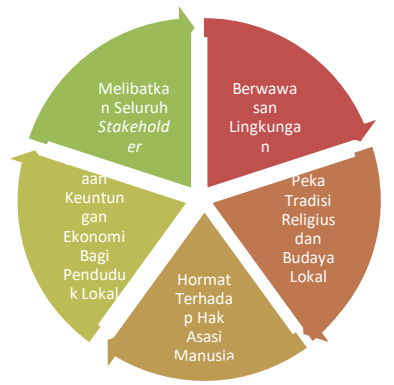

Gambar 1: Dimensi Wisata Berkelnjutan

\footnotetext{
${ }^{28}$ Wawancara dengan Iwan Firman Widiyanto sebagai Penasehat Creative and Peace Srumbung Gunung Society (CPSS). CPSS adalah perkumpulan yang dibentuk oleh masyarakat dusun Srumbung Gunung sebagai pengelola DWKP. Anggota CPSS sebagian besar adalah anak-anak muda lintas agama dan kepercayaan. Semangat dan kekompakan mereka juga menjadi salah satu modal sosial dalam pembangu-nan DWKP
} 


\section{Melibatkan Seluruh Stakeholder}

Salah satu prinsip dalam untuk menciptakan wisata yang berkelanjutan adalah pentingnya melibatkan seluruh stakeholder. Hal ini sesuai dengan nuansa makna shalom yang menunjuk kepada hubungan sosial yang damai, relasi positif yang baik di antara kelompok-kelompok (stake-holder). Kata "shalom" dalam hubungan sosial berarti memiliki hubungan yang baik dengan sesama, dengan masyarakat, atau antara bangsa ataupun kelompok (1Raj. 5:12). Shalom digunakan dalam aturan yang baik dalam bangsa Israel dan juga perjanjian dengan bangsa-bangsa lain (Bil. 25:12; Yeh. 34:26; 37:26). Ketika aturan yang baik tersebut dijalankan, maka terjadilah hubungan sosial yang harmonis, atau hubungan yang damai. ${ }^{29}$

Prinsip ini diimplementasikan melalui Focus Group Discussion (FGD) dan Deklarasi pembentukan DWKP di Dusun Srumbung Gunung, Desa Poncoruso, Kabupaten Semarang. Para stakeholder desa, mulai dari kepala desa, BPD, kepala dusun, ketua RT/RW, pengurus karang taruna, pengurus PKK, pengurus CPSS, dan warga desa. FGD bertujuan untuk menyatukan Visi Misi dan penyamaan persepsi terkait pembentukan DWKP di Dusun Srumbung Gunung. Sedangkan deklarasi sebagai bentuk komitmen seluruh warga untuk mendukung terbentuknya Dusun Srumbung Gunung menjadi DWKP. Selain FGD dan deklarasi pembentukan DWKP, CPSS bekerjasama dengan TIM Pengabdian kepada Masyarakakat (PkM) Universitas Kristen Satya Wacana mengadakan pelatihan manajemen pariwisata bagi seluruh pemangku kepentingan. Pelibatan seluruh pemangku kepentingan adalah salah satu prinsip yang penting yang harus dilakukan dalam pembangunan wisata perdamaian. Hal ini selaras dengan pandangan Salazar, diperlukan dialog terus menerus di antara semua pemangku kepentingan untuk membangun wisata damai.

\section{Berwawasan Lingkungan}

Membuat dan mengimplementasikan desain tata ruang desa yang mengekspresikan secara kuat simbolisasi desa yang kreatif dan damai dengan memperhatikan pelestarian ekologi. Hal ini sesuai salah satu definisi damai IIPT yaitu damai dengan alam. Dalam perspektif sosioteologis, ini sebagai perwujudan dari nuansa makna relasional shalom yang bukan saja berdamai dalam relasinya dengan sesama manusia tetapi juga berdamai dengan alam. Visi shalom sendiri adalah menciptakan damai sejahtera atas dunia dan segenap ciptaan. Dalam konteks pembuangan, misalnya, konsep shalom terwujud dalam tanggung jawab orang Israel di pembuangan. Nabi Yeremia menegaskan bahwa meskipun mereka ada di Babel, tidak menjadi halangan bagi mereka untuk membangun relasi dengan Allah, dengan sesama, dengan diri sendiri dan dengan alam. Melalui kerja keras mereka dalam mengelola tanah, mereka dapat menikmati hasil dari tanah yang mereka olah. Tanggung jawab mengelola tanah dengan berkebun dan menggunakan hasil alam untuk membangun tempat tinggal, merupakan sikap yang harus mereka tunjukkan sebagai umat Allah di tengah-tengah bangsa lain. ${ }^{30}$

Karang Taruna Mudhatama Dusun Srumbung Gunung telah melakukan penanaman pohon di sepanjang jalan baru. Lokasinya berada di sebelah timur wilayah Dusun Srumbung

\footnotetext{
${ }^{29}$ Marbun, T. O., "Shalom Sebagai Konsep Keselamatan Yang Holistik”, Jurnal Luxnos, 5 no. 2 (2019): 147-157. https://doi.org/10.47304/jl.v5i2.23

${ }^{30}$ Zinzendorf Dachi, "Menghadirkan Shalom Berdasarkan Yeremia 29:4-7”, ILLUMINATE: Jurnal Teologi dan Pendidikan Kristiani. Vol 1, No 1, Juni 2018 (43-58)
} 
Gunung. Penanaman pohon tersebut dimaksudkan untuk menata wajah desa menjadi lebih sejuk dan indah. Saat ini di area tersebut pada musim kemarau sering nampak gersang karena kendala air sehingga para petani kesulitan untuk bercocok tanam. Penanaman pohon diharapkan juga mampu menjadikan area yang gersang tersebut sebagai daerah peresapan air. Sehingga, mampu menjaga kelembapan tanah di musim kemarau. Selain itu, penanaman pohon juga mempunyai tujuan untuk menjadi daya tarik bagi wisatawan. Mereka menjadi lebih nyaman jika berkunjung dan menikmati alam pedesaan di Dusun Srumbung Gunung.

Di tingkat Rukun Tetangga, warga masyarakat Dusun Srumbung Gunung telah dihimbau untuk mengelola sampah dengan baik. Sebelum isu tentang perintisan Desa Wisata bergulir, beberapa warga masih membuang sampah rumah tangganya secara sembarangan. Maka di sungai-sungai kecil dan di kebun masih banyak ditemukan bekas pampers dan plastik sampah. Pada saat ini kebiasaan buruk warga dalam membuang sampah sembarangan semakin dapat diminimalisir. Dalam pertemuan-pertemuan rapat RT persoalan pengelolaan sampah terus-menerus digulirkan agar menjadikan Dusun Srumbung Gunung lebih bersih dan sehat, sehingga dapat mendukung dalam upaya perintisan DWKP. Pemerintah Desa Poncoruso bahkan telah mengajukan kepada pemerintah kabupaten melalui dinas terkait untuk mendukung pembuatan tempat pengolahan sampah di Dusun Srumbung Gunung. Perencanaan ini sangat mendukung perwujudan DWKP. Tidak bisa diabaikan bahwa salah satu dampak negatif perkembangan pariwisata saat ini adalah masalah sampah yang ditinggalkan oleh para wisatawan.

\section{Peka Tradisi Religius dan Budaya Lokal}

Salah satu ketakutan yang dihadapi orang Kristen ketika membuka diri dengan budaya dan tradisi untuk didialogkan dengan ajaran Alkitab adalah sinkretisme. Praktik seperti ini dianggap sebagai yang berpotensi merusak pengajaran Injil keselamatan Allah di dalam Kristus. ${ }^{31}$ Tetapi, sebenarnya tidak ada satupun agama di dunia yang tidak bersifat sinkretis, dalam pengertian genuine merumuskan pandangan dunianya tanpa melibatkan unsur-unsur kultural dari kebudayaan setempat di mana agama itu hadir. Setiap agama dan sistem kepercayaan dalam merumuskan struktur pandangan dunia dan rumusan teologisnya akan menggunakan unsur-unsur budaya setempat sebagai dasar pijakan. Itulah sebabnya berbeda satu dengan lain dalam hal bahasa, isi ajaran, ritus, hingga pandangan teologi. ${ }^{32}$ Tidak ada satu pun agama yang ajaran teologis etis dan ritusnya langsung diturunkan dari sorga. Hal itu selalu terjadi dalam interaksi dengan budaya dan dunia sekitarnya. Berdasarkan pemahaman tersebut, jika kembali kepada salah satu makna shalom sebagai harmony, maka shalom paling baik direfleksikan dalam konteks komunitas multikultural, karena ketika semua budaya bersatu, di situlah kehadiran damai Tuhan menjadi nyata. Apa yang dilakukan oleh masyarakat Srumbung Gunung yang hidup dalam harmoni di tengah multikulturalisme agama, budaya dan tradisi adalah perwujudan nilai harmoni shalom.

\footnotetext{
${ }^{31}$ Ebenhaizer I. Nuban Timo, Polifonik Bukan Monofonik, Sebuah Pengantar Berteologi dari Perspektif Sosiologi Agama (Salatiga: Satya Wacana University Press, 2019), 255.

${ }^{32}$ Sumanto Al Qurtuby, Sinkretisme dalam Islam Jawa. Jurnal Waskita: Jurnal Studi Agama dan Masyarakat. Salatiga, Universitas Kristen Satya Wacana, April 2004.
} 
Dusun Srumbung Gunung kaya akan tradisi religius dan budaya lokal. Masyarakat masih menghidupi berbagai tradisi religius dan budaya lokal seperti: bersesaji, kenduri/slametan, nyadran, dawuhan, sambatan, sinoman, tahlilan, dan penghiburan. Beberapa masyarakat masih melakukan tradisi ini ketika hendak menyelenggarakan acara pernikahan, pembuatan atau perbaikan rumah. Kenduri/slametan merupakan acara berdoa bersama dengan mengundang tetangga untuk mendoakan roh dari keluarga yang meninggal supaya selamat atau berdoa untuk keselamatan keluarga, Nyadran adalah tradisi berdoa bersama seluruh warga masyarakat di makam leluhur. Dawuhan adalah tradisi gotong royong untuk membersihkan sumber dan saluran air untuk pertanian. Sambatan adalah gotong royong membantu tetangga yang mempunyai kerja misalnya mendirikan rumah. Sinoman merupakan tradisi kerjasama dalam membantu dalam meringankan beban tetangga yang mempunyai kerja misalnya pernikahan. Tahlilan adalah doa bersama yang dilakukan warga masyarakat Muslim dalam mendoakan keluarga yang baru saja meninggal. Penghiburan adalah ibadah bersama warga Kristiani untuk memberikan penghiburan kepada keluarga yang sedang berduka karena anggotanya yang telah meninggal. Baik tahlilan dan penghiburan dilakukan bersama antara warga Muslim dan Kristiani. Nilai-nilai yang diangkat di sini bukan semata pada implementasi dari kepekaan terhadap tradisi religius dan budaya lokal, tetapi juga nilai-nilai kerukunan dan harmoni yang diciptakan melalui pelestarian tradisi keagamaan dan budaya lokal.

Dalam perancangan DWKP tim Creative Peace Srumbung Society (CPSS) telah mendiskusikan untuk mengemas tradisi budaya untuk menjadi daya tarik bagai para pengunjung dalam menikmati situasi pedesaan. Dalam laman: www.srumbunggunung.org dapat dilihat paket atraksi seni dan budaya menyajikan kesempatan bagi pengunjung untuk menikmati pengalaman berkenduri, mengikuti nyadran dan dawuhan. Selain itu pengunjung juga dapat belajar kesenian seperti berlatih menari atau memainkan gamelan. Konsep wisata ini menunjukkan bahwa DWKP menjadi sarana untuk memperkenalkan, melestarikan dan bahkan mengembangkan tradisi religius dan budaya masyarakat Srumbung Gunung. Potensi seni dan budaya yang terdapat dalam masyarakat diberdayakan untuk mendukung kesejahteraan masyarakat itu sendiri.

\section{Hormat terhadap Hak Asasi Manusia}

Perancangan dan implementasi DWKP juga memperhatikan penghormatan terhadap Hak Asasi Manusia. Prinsip ini sangat relevan dengan makna keadilan didalam shalom, yang bukan bersifat pasif terhadap status quo, tetapi aktif melawan semua bentuk penindasan, eksploitasi dan keti-dakadilan hukum dan mentransformasikan situasi-situasi tersebut menuju keadilan. Keadilan berarti memperlakukan semua orang secara setara, untuk memperjuangkan keadilan tidak bisa tidak seseorang harus menghargai hak orang lain sebagai sesama manusia.

Ada humanisme religius yang kuat dalam Alkitab, yang oleh beberapa pemikir Yahudi modern dilihat sebagai dasar liberalisme gaya Barat dan Deklarasi Hak Asasi Manusia; diciptakan menurut Gambar Allah. Sebagai contoh, menurut Kitab Suci, manusia diciptakan "menurut gambar Allah" (Kej. 1:27; be-tselem Elo-him). Artinya, setiap manusia memiliki aspek keilahian, dan karena itu memiliki nilai pribadi yang tidak bersyarat. Jika semua umat manusia diciptakan menurut gambar Tuhan, dan semuanya diturunkan dari satu ibu, Hawa, maka tidak ada hierarki yang melekat dan semuanya setara. Ada kesepakatan universal dalam 
sumber thetalmudic, bahwa baik Yahudi maupun non-Yahudi diciptakan dalam gambar Tuhan. Sebuah bagian dalam Mish-nah (mSan 4:5), yang sering dikutip oleh orang Yahudi kontemporer, mengungkapkan nilai tak terbatas dari setiap individu: Mengapa Adam diciptakan sendiri? Untuk mengajari Anda bahwa siapa pun yang menghancurkan satu manusia dianggap telah menghancurkan seluruh dunia; dan siapa pun yang menyelamatkan satu manusia dianggap oleh Kitab Suci memiliki seluruh dunia. ${ }^{33}$

DWKP Srumbung Gunung adalah sebuah tindakan aksi untuk mewujudkan penghargaan terhadap HAM dengan mencipatakan damai di antara sesama manusia dengan latar belakang budaya dan agama yang berbeda-beda. Jika menilik paket-paket Peace Camp yang terdapat di website www.srumbunggunung.org memperlihatkan fokus perhatian utama DWKP terhadap isu-isu HAM seperti penghormatan terhadap perbedaan agama, etnis/suku, gender, jenis kelamin dan keanekaragaman yang lain. Implementasi penghormatan terhadap HAM juga dinyatakan melalui kenggotaan CPSS yang multireligius. Dalam pertemuan atau rapat bersama untuk mencapai keputusan juga senantiasa mempertimbangkan proporsi keterwakilan perempuan. Penghormatan terhadap HAM menjadi perhatian utama karena DWKP mengusung konsep untuk menjadi desa yang merawat dan mempromosikan nilai-nilai perdamaian baik secara lokal, nasional dan global.

\section{Pemeratan Keuntungan Ekonomi bagi Masyarakat Lokal}

Prinsip pemerataan ekonomi bagi masyarakat lokal sangat relevan dengan perspektfif sosioteologis shalom, di mana makna shalom sebagai misi holistik yang harus diperjuangkan gereja sebagai cara hidup, yaitu memperjuangkan keselamatan (materiil maupun spiritual) dan keadilan di tengah kehidupan masyarakat. Dalam konteks sustainable tourism, pemerataan kesejahteraan dan keadilan bagi penduduk lokal. CPSS bekerjasama dengan Akademisi Tim PkM Universitas Satya Wacana melakukan pemberdayaan SDM bagi penduduk lokal melalui pelatihan-pelatihan, di antaranya adalah: Pelatihan sablon untuk meningkatan keterampilan Karang Taruna Muda Tama (KTMT); pelatihan ketrampilan kuliner dan pembuatan jamu kekinian bagi ibu-ibu dan bapak penduduk lokal; pelatihan manajemen homestay bagi masyarakat lokal bagi penduduk yang rumahnya akan difungsikan sebagai homestay; dan pelatihan pengelolaan website dan online marketing, agar semua hasil produk baik pertanian, kuliner, sablon dan produk-produk lainnya dapat dipasarkan secara online melalui fitur pasar dusun. Semua pelatihan tersebut dilakukan sebagai bagian dari implementasi untuk menciptakan pemerataan dan peningkatan kesejahteraan masyarakat lokal.

\section{Produk DWKP}

Pembahasan tentang produk DWKP mengacu kepada dua aspek, yaitu: kreatif dan perdamaian. Tetapi lebih memokuskan pada pengembangan aspek perdamaian sebagai branding desa wisata. Beberapa produk wisata desa kreatif perdamaian yang ditawarkan ada beberapa bentuk atau paket. Pertama, paket live in lintas agama dan iman, di mana peserta mengambil bagian dalam kehidupan keseharian masyarakat untuk melihat secara langsung nilai-nilai kearifan lokal seperti kerukunan dan kegotongroyongan yang masih dihidupi oleh masyarakat Srumbung Gunung. Kedua, paket Peace Education, yakni dalam bentuk pelatihan 12 nilai

${ }^{33}$ Sunggu Yang, "Human Rights and the Bible" (2016). Faculty Publications - College of Christian Studies. 253.http://digitalcommons.georgefox.edu/ccs/253 
dasar perdamaian: menerima diri, prasangka, perbedaan etnis, perbedaan agama, perbedaan jenis kelamin, perbedaan status ekonomi, perbedaan kelompok dan genk, keanekaragaman, konflik, menolak kekerasan, mengakui kesalahan dan memberi maaf. Ketiga, paket outing/ live in, yakni wisatawan menginap di homestay (rumah penduduk), mengikuti aktivitas keseharian yang dilakukan oleh penduduk seperti ikut menanam padi, panen, memberi makan ternak, tracking sungai, napak tilas situs bersejarah. Keempat, festival budaya dan kuliner tradisional, yakni sebuah event tahunan yang diadakan sebagai bagian dari peletarian budaya dan kesenian tradisional seperti: jaran kepang, karawitan, dan qasidah. Sedangkan dalam festival kuliner tradisional dijajakan berbagai bentuk dan ragam kuliner tradisional khas Srumbung Gunung.

\section{Kesimpulan}

Ancaman disintegrasi di Indonesia semakin besar. Ini terlihat dari banyaknya munculnya konflik, intolerasi, radikalisme, dan politisasi agama. Kondisi ini tidak boleh dibiarkan. Pariwisata ditemukan sebagai pendekatan yang berguna untuk menggerakan perdamaian, seperti yang digagas oleh D'Amore (1988; 2014). Dusun Srumbung Gunung adalah desa yang dirintis menjadi Desa Wisata Kreatif Perdamaian. Pembangunan desa ini memperhatikan prinsipprinsip sustainable tourism, seperti melibatkan seluruh stakeholder, berwawasan lingkungan, peka tradisi religius dan budaya lokal, hormat terhadap hak asasi manusia, dan pemerataan keuntungan ekonomi bagi masyarakat Dusun Srumbung Gunung. Nilai-nilai tersebut sangat relevan dengan perpspektif sosio-teologis shalom, seperti prinsip pentingnya melibatkan seluruh stakeholder yang sangat relevan dengan hubungan sosial yang damai, relasi positif yang baik di antara kelompok-kelompok dan berkeadilan. Prinsip berwawasan lingkungan perspektif sebagai sebuah cara hidup untuk mewujudkan misi Allah (mission of God) menciptakan damai sejahtera di dunia dan segenap ciptaan, termasuk didalamnya alam semesta. Demikian juga dengan ketiga prinsip selajutnya sangat relevan jika dikaitkan dengan nilai-nilai shalom, keselamatan (spiritual dan material), keadilan (untuk segenap ciptaan), dan perdamaian. Karena itu, implementasi nilai-nilai tersebut dapat menjadi salah satu upaya untuk menghadirkan shalom (damai) di tengah ancaman disintegrasi bangsa. Menghadirkan kedamaian dalam hubungan antara manusia dengan Tuhan, menciptakan harmoni di antara sesama anak bangsa meskipun berbeda suku, ras dan agamanya, berdamai dengan alam melalui merawat lingkungan alam dan memelihara warisan budaya, serta berdampak pada peningkatan kesejahteraan sosial dan ekonomi bagi masyarakat lokal. Relevansi prinsip-prinsip Sustainable Tour dan nilai-nilai perdamaian shalom yang diimplementasikan dalam DWKP Srumbung Gunung dapat menjadi salah satu kontribusi lokal (desa) bagi penciptaan kerukunan dan persatuan bangsa.

\section{Ucapan Terima kasih}

Pada kesempatan ini perkenankan kami menyampaikan terima kasih kepada: Pertama, DRPM Dikti yang telah memberikan hibah pengabdian program pengembangan Desa Wisata Kreatif Perdamaian Srumbung Gunung. Kedua, pengurus Creative and Peace Srumbung Gunung Society (CPSS) Srumbung Gunung, secara khusus Pdt. Iwan Firman Widiyanto, yang berkenan membantu menyediakan data lapangan terkait pengembangan Desa Wisata Kreatif Perda- 
maian. Ketiga, kepada rekan-rekan Tim PkM UKSW, Rini Kartika Hudiono yang telah membantu memberikan referensi penting terkait sustainable tours. Demikian juga kepada Evi Maria dan Suharyadi yang telah bekerja keras mengedit dan menyempurnakan penulisan artikel ini.

\section{Referensi}

Arjon, Sugit. Religious Sentiment in Local Politics. Jurnal Politik, Vol. 3, No. 2. (Februari 2018):171

Ariana, Nyoman. Penelusuran Wisata Damai Monumen Ground Zero Kuta. Bali: Pustaka Larasan, 2017.

Azra, Azyumardi, Intoleransi Keagamaan, https://ppim.uinjkt.ac.id/penelitian/intoleransikeagamaan/; diakses 9 September 2020

Al Qurtuby, Sumanto Sinkretisme dalam Islam Jawa. Jurnal Waskita: Jurnal Studi Agama dan Masyarakat. Salatiga, Universitas Kristen Satya Wacana, April 2004.

Budeanu, Adriana Impacts and responsibilities for sustainable tourism: A tour operator's perspective. Journal of Cleaner Production, 13, 2, (2005): 89-97.

Butler, R. W., \& Mao, B. (1995). Tourism between divided quasi-states: International, domestic or what? In R. W. Butler \& D. Pearce (Eds.), Change in Tourism: People, Places, Processes (pp. 92-113). Routledge.

Butler, D. Pearce (Eds.). Change in tourism: People, Places, Processes. London: Routledge, 1995.

Gupta, K. R. \& Richa A.Qualitative Research in Management Methods and Experiences, Los Angeles: Sagepublication, 2015

Creswell, J. (2002). Desain Penelitian Pendekatan Kualitatif dan Kuantitatif. KIK Press.

D'Amore, L. (1988). Tourism - The World's Peace Industry. Journal of Travel Research, 27(1), 35-40. https://doi.org/10.1177/004728758802700107

D’Amore, L. (2014). Peace through Tourism: An Historical and Future Perspective. In P. E. of the K. the Centre of Peace Research University/Austria (Ed.), International Handbook on Tourism and Peace (pp. 355-368). Drava. https://doi.org/10.18111/9783854357131

Dachi, Zinzendorf. Menghadirkan Shalom Berdasarkan Yeremia 29:4-7. ILLUMINATE: Jurnal Teologi dan Pendidikan Agama Kristen; Jurnal Teologi dan Pendidikan Kristiani. Vol 1, No 1, Juni 2018 (43-58)

Farahani, B. M., \& Dogra, J. (2014). An Inter-Relational Study of Achieving Peace Through Tourism. In P. S. Manhas, D. R. Gupta, \& A. Gupta (Eds.), Strategic Development Policies and Impact Studies of Sustainable, Rural and Community - based Tourism (Issue July, pp. 127-137). Primus Book.

Kotler, Philip and Waldemar Pfoertsch. B2B Brand Management, with the Cooperation of Ines Michi. Berlin: Springer, 2006

Litvin, S. W. (1998). Tourism: The World's Peace Industry? Journal of Travel Research, 37(1), 63-66. https://doi.org/10.1177/004728759803700108

Marbun, T. O. (2019). Shalom Sebagai Konsep Keselamatan yang Holistik. Jurnal Luxnos, 5(2), 147-157. https://doi.org/10.47304/jl.v5i2.23

Mckercher, B. (2003). Sustainable Tourism Development - Guiding Principles for Planning and Management. National Seminar on Sustainable Tourism Development, 1-10.

Nuban Timo, Ebenhaizer I., Polifonik Bukan Monofonik, Sebuah Pengantar Berteologi dari Perspektif Sosiologi Agama. Salatiga: Satya Wacana University Press, 2019.

Salazar, N. B. (2006). Building a "Culture of Peace" through Tourism: reflexive and analytical notes and queries. In Universitas Humanística (Issue 62). 
Schneider, E. M. (2019). Touring for peace: the role of dual-narrative tours in creating transnational activists. International Journal of Tourism Cities, 5(2), 200-218. https://doi.org/10.1108/IJTC-12-2017-0092

Siahaan, Harls Evan. "Mengajarkan Nasionalisme Lewat Momentum Perayaan Paskah: Refleksi Kritis Keluaran 12:1-51", DUNAMIS (Jurnal Teologi dan Pendidikan Kristiani), Vol. 1, No. 2, (April 2017): 45.

United Nations Environment Programme, \& World Tourism Organization. (2005). Making Tourism More Sustainable: A Guide for Policy Makers. UNEP.

Wohlmuther, C.\& Werner W.(Ed.), 2013, International Handbook on Tourism and Peace, Centre for Peace Research and Peace Education of the Klagenfurt University/Austriain cooperation with World Tourism Organization (UNWTO

Yoder, Perry B. Shalom the Bible's Word for Salvation, Justice and Peace (Newtown: Faith and Life Press, 1987),

Yang, Sunggu, "Human Rights and the Bible" (2016).Faculty Publications - College of Christian Studies. 253.http://digitalcommons.georgefox.edu/ccs/253 